\title{
Cytological Studies in Digitaria pentzii Stent
}

\author{
K. G. Shambulingappa ${ }^{1}$
}

\section{INTRODUCTION}

The species belonging to the genus Digitaria, tribe Panicae, are mostly tropical forage grasses. Two economically important are $D$. decumbens Stent and $D$. pentzii Stent. Both species grow under similar ecological conditions in Africa according to Oakes (4). ${ }^{2}$

Pangolagrass ( $D$. decumbens) is one of our better forage grass introductions. It has become a highly appreciated pasture grass in Puerto Rico, throughout the Tropics, and in some parts of southern U.S. Pangolagrass, however, has some inherited disadvantages. It is highly sterile, produces practically no seed and is susceptible to stunt virus. It has been impossible, thus far, to improve this grass species by means of hybridization.

Grass varieties belonging to $D$. pentzii, on the other hand, have most of the desirable qualities of Pangolagrass and are among our best known pasture and erosion control grasses. Furthermore, some pentzii lines have several additional advantages over Pangolagrass, viz: 1 , They are more widely distributed and have a wide range of genotypes and ecotypes; 2 , they are sexually fertile and produce a fair amount of seeds; and 3, strains are available that are resistant or tolerant to cold, stunt virus and other diseases and pests $(2,5)$.

Because of these important and useful characteristics of pentzii over decumbens, it has been felt that different lines of pentzii can be utilized in the Digitaria breeding program. Need for cytological analyses of some Digitaria introductions from Africa naturally became self-evident.

In the present study, 14 different accessions of $D$. pentzii were analysed cytologically. Chromosome number, their configurations at diakinensis and metaphase 1, gross morphology of pachytene chromosomes, pollen stainability and nature of ploidy were studied.

\section{MATERIALS AND METHODS}

The following accessions of Digitaria pentzii were used in the present study:

P.I. 299740 (P.R. 6389)

P.I. 299744 (P.R. 6509)
P.I. 299753 (P.R. 6442)

P.I. 299763 (P.R. 6673)

1 Associate Cytogeneticist, Agricultural Experiment Station, Mayagüez Campus, University of Puerto Rico, Río Piedras, P.R.

2 Italic numbers in parentheses refer to Literature Cited, p. 408. 
P.I. 299745 (P.R. 6417)

P.I. 299747 (P.R. 6422)

P.I. 299748 (P.R. 6431)

P.I. 299750 (P.R. 6532)

P.I. 299751 (P.R. 6663)
P.I. 299768 (P.R. 6678)

P.I. 299770 (P.R. 6573)

P.I. 299771 (P.R. 6574)

P.I. 299774 (P.R. 6458)

P.I. 299777 (P.R. 6680)

The vegetative stocks of the above 14 accessions were obtained in 1964 through the USDA Plant Introduction Station, Glendale, Maryland, and are being maintained in pots. They constitute a part of the Dr. A. J. Oakes' collection of the species of Digitaria from Africa.

Panicles for cytological study were fixed in three parts alcohol and one part propionic acid, the latter having previously been saturated with ferric acetate for a minimum of 24 hours (14). Anthers directly from the fixative were used to make smear preparations. The pollen was stained with equal amounts of 1-percent acetocarmine and glycerol. To get the percentage range of pollen stainability, about 8 to 10 slides were prepared from the same plant and a minimum of 600 pollen grains per slide were counted. All cytological analyses were made with a Leitz Ortholux microscope fitted with phase contrast. Photographs were taken from fresh slides using a green filter.

\section{OBSERVATIONS}

Table 1 gives detailed information on chromosome number, range of chromosome configurations at diakinensis and metaphase 1 and pollen stainability of all 14 accessions. Ten of the 14 accessions are tetraploids $(2 n=36)$; two are triploids; one is a diploid $(2 n=18)$ and one is an aneuploid $(2 n=34)$. One of the tetraploids, P.I. 299774 (P.R. 6458) has, in addition, three $B$ chromosomes (fig. 1). Their morphology and behavior during meiosis have been reported elsewhere. Meiosis, in general, was mostly normal in all the ten tetraploids and one aneuploid. Bivalents usually were seen at diakinesis and metaphase I (figs. 2, 3, 4). However, rarely PMCs with one to two quadrivalents were seen at these stages in all the 11 accessions (figs. 5, 6, 7). Sometimes a trivalent accompanied by a univalent also was seen. In the accession P.I. 299763 (P.R. 6673), a high frequency of univalents was recorded both at diakinesis and metaphase I.

Anaphase I mostly was regular with normal disjunction and equal distribution (fig. 8). Very rarely, however, a chromatin bridge or delayed separation of a bivalent was encountered (fig. 9). Telophase I and second meiotic divisions apparently were normal. A good percentage of stainable pollen ranging from 60 to 80 was recorded except in accession P.I. 299763, in which the pollen stainability ranged from 40 to 50 percent.

Meiosis in both the triploids was highly irregular. A maximum of nine 


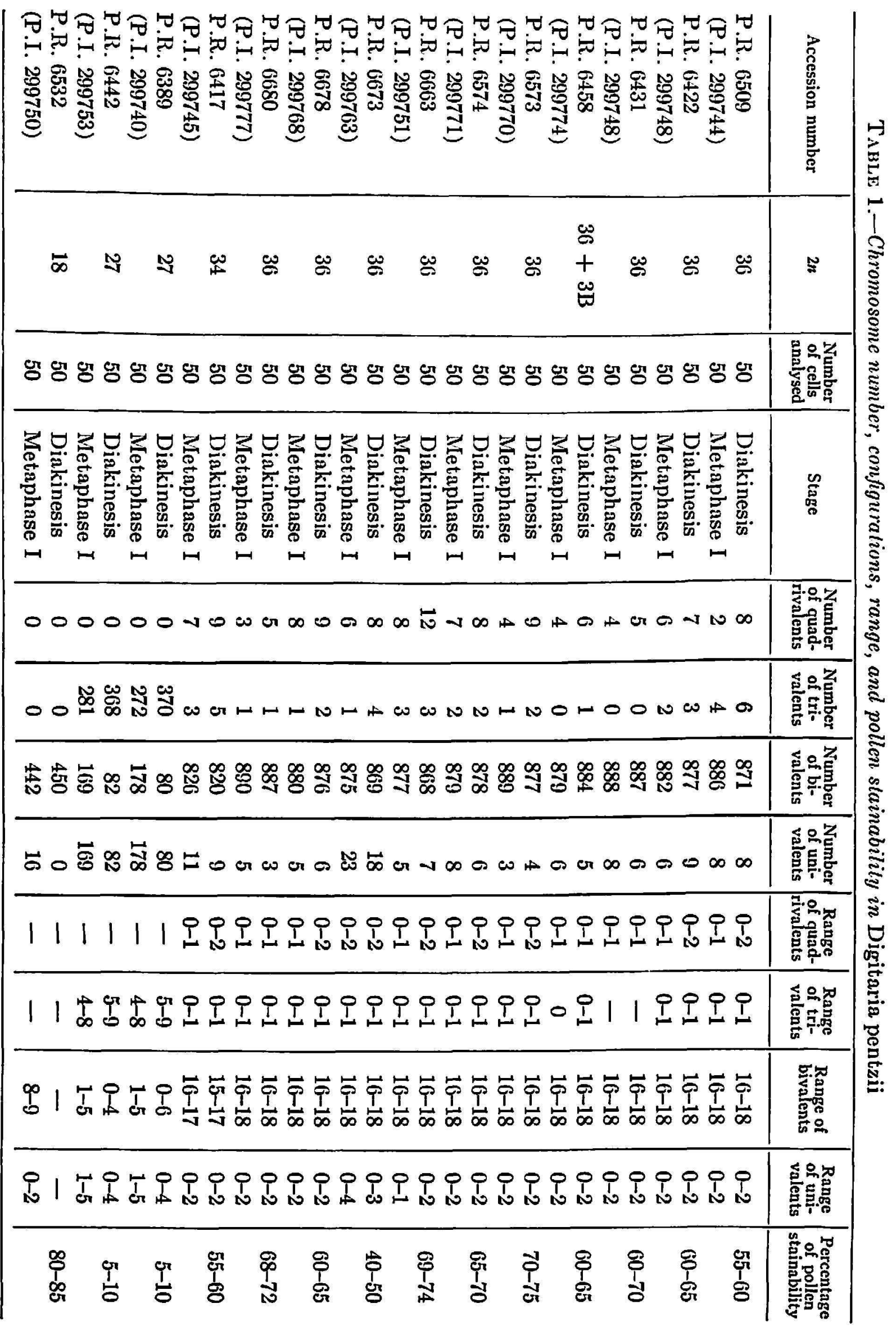




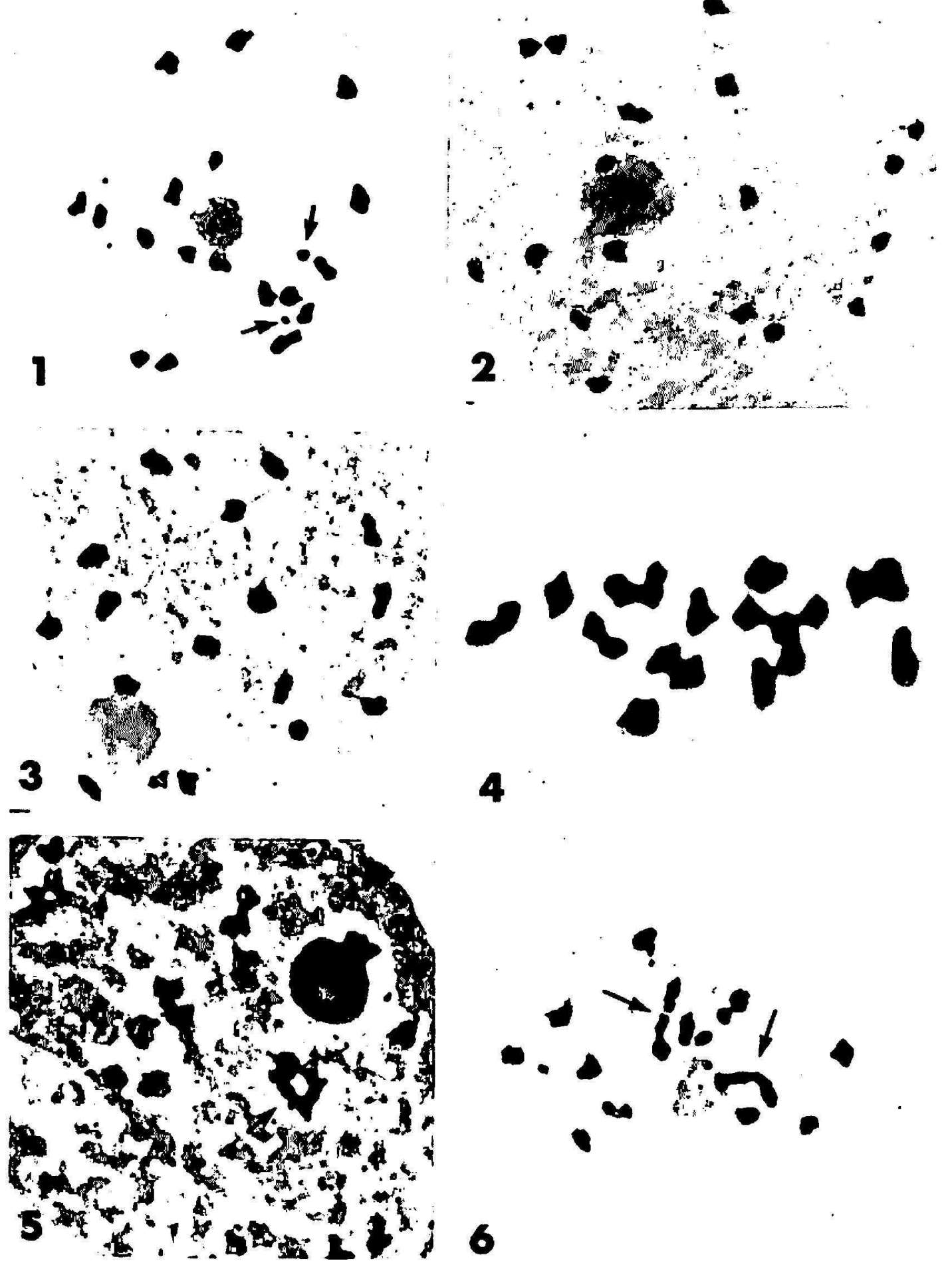

FIG. 1.-Diakinesis showing $18_{\mathrm{II}}+1_{\mathrm{II}} \mathrm{B}+1_{\mathrm{I}} \mathrm{B}(\uparrow)$ in Digilaria pentzii (P.R. 6458) $(\times 1000)$.

FIgs. 2 and 3.-Diakinesis showing $18_{\mathrm{II}}$ and $17_{\mathrm{II}}$ in Digitaria pentzii (Ac. No. P.R. 6663 ) and $D$. pentzii (Ac. No. P.R. 6417), respectively $(\times 1000)$.

Fig. 4.-Metaphase I (Ac. No. P.R. 6663) 18 bivalents $(\times 1800)$.

Figs. 5 and 6.-Diakinesis showing 1 ring quadrivalent and 2 chain quadrivalents $(\uparrow)$ in the accessions P.R. 6663 and P.R. 6417 respectively $(\times 1000)$. 

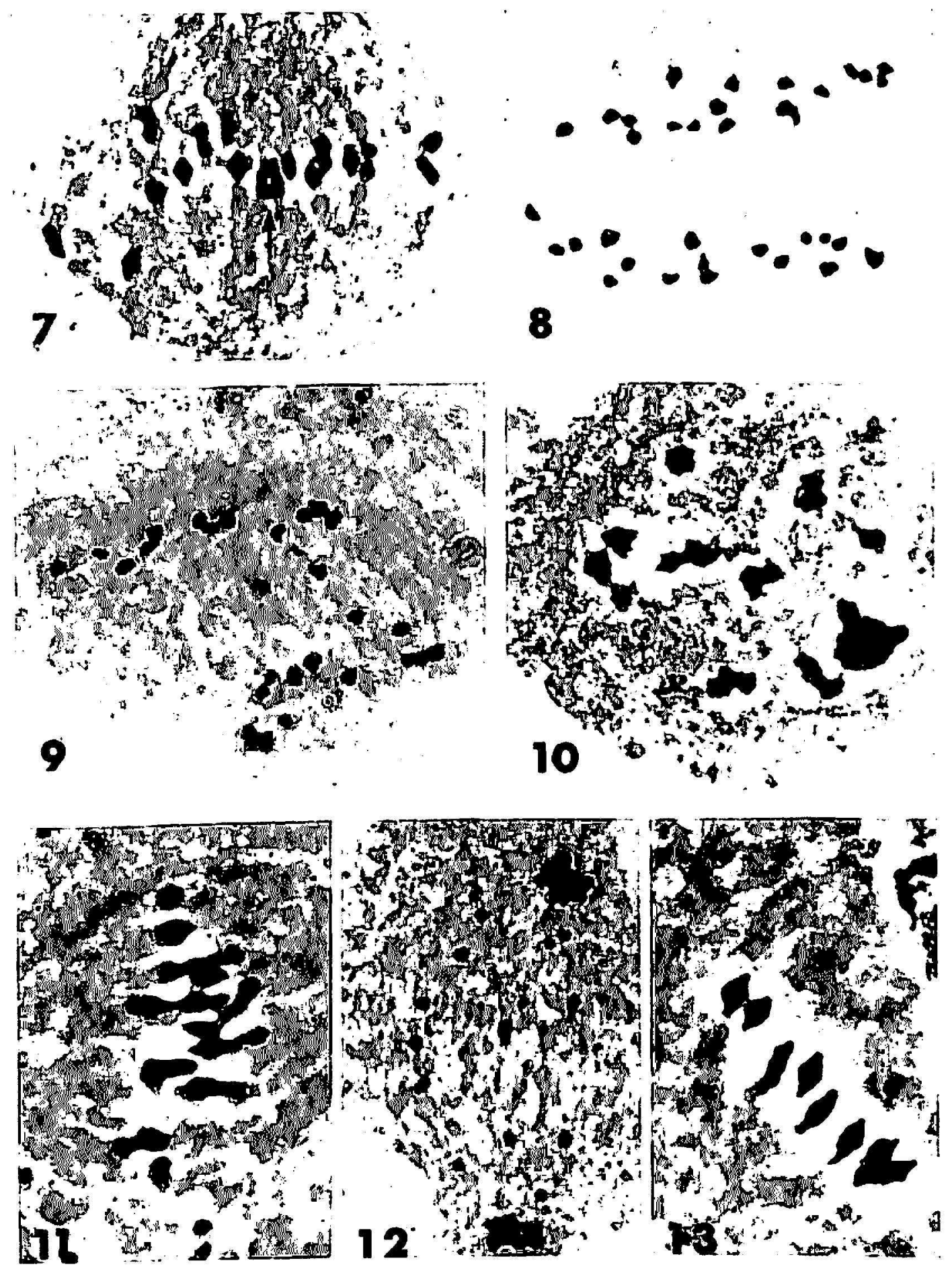

Fig. 7.-Metaphase I with $15_{I I}+1_{\text {IV }}$ (Ac. No. P.R. 6663) $(\times 1000)$.

FIG. 8.-Anaphase I (Ac. No. P.R. 6663) showing normal distribution of 18 chromosomes $(\times 1000)$.

Frg. 9.-Anaphase I showing chromatin bridge (Ac. No. P.R. 6663) $(\times 1000)$.

Frg. 10.-Diakinesis showing $7_{I I I}+2_{I I}+2_{I}$ (Ac. No. P.R. 6442) $(\times 1200)$.

FIG. 11.-Metaphase I (Ac. No. P.R. 6442) with $7_{I I I}+2$ II +2 I $(\times 1500)$.

Fra. 12.-Anaphase I with lagging chromosomes (Ac. No. P.R. 6442) $(\times 1000)$.

FIG. 13.-Metaphase I (Ac. No. P.R. 6532) showing 9 regular bivalents $(\times 1500)$. 
trivalents at diakinesis and eight at metaphase I with a range of 5 to 9 and 4 to 8 , respectively, were seen (figs. 10 and 11 ). The univalents range from one to five both at diakinesis and metaphase I. Anaphase I was mostly abnormal. Lagging of chromosomes and unequal distribution were seen regularly (fig. 12). Likewise, second meiotic divisions also were irregular resulting in monads, dyads and triads in addition to abnormal tetrads. The pollen was highly sterile. The diploid accession showed a very normal meiosis with regular bivalents both at diakinesis and metaphase I (fig. 13). High percentage of pollen stainability also was recorded.

Although no detailed analysis of pachytene chromosomes has been made in these accessions, preliminary studies on the gross morphology of the pachytene chromosomes in tetraploids (includes aneuploid $2 n=34$ ) revealed that there are two types of pachytene chromosomes comparable to two of the four types reported by the author in some diploid species. In triploids, no basic differences were seen in the morphology of the pachytene chromosomes. In other words, each chromosome was represented thrice and these seemed to be very similar in their morphology. In diploid accessions, the pachytene chromosomes stain uniformly and the centromeres are difficult to locate. Detailed studies on the pachytene chromosomes will, however, be undertaken both in diploid and tetraploid types of this species.

\section{DISCUSSION}

Studies on the cytology of the species of Digitaria were centered initially in the reporting of chromosome numbers $(3,7,15,16,18)$. In recent years, however, more detailed studies have appeared in the literature $(6,8,9,10,11$, 17) because of the increasing importance of several of the species. A collection of over 400 Digitaria accessions maintained by Plant Introduction, USDA, contains a large collection made in Africa by Dr. A. J. Oakes (4). This collection provides a wide variety of germ plasm; also enough material to analyse cytologically and thus perhaps modify the classical taxonomy. based on external morphological characters of the plant.

The genus Digitaria is interestingly very complex in the sense that the same species contain types with different chromosome numbers (1). Furthermore, it appears from the available literature that a high percentage of the species of Digitaria are polyploid (about 70 percent) and especially tetraploid types. Different chromosome numbers have been reported by previous workers for D. pentzii: $2 n=18$ and $36(8)$, and $2 n=54(3)$. In the present study accessions with different chromosome numbers also have been encountered. Eleven of the 15 accessions have $2 n=36$, two have $2 n=27$ and each of the two remaining have $2 n=18$ and 34 . The frequency of quadrivalents in all the tetraploids and one aneuploid is considerably low. Based on the chromosome configurations in the tetraploids which is mostly 
bivalent formation, it can be said that all the tetraploids are allopolyploids and behave like functional diploids.

Four types of pachytene complements in nine diploid accessions of Digitaria have been reported (9). The present preliminary studies on the gross morphology of pachytene chromosomes of the tetraploids, indicate that they contain two types of pachytene complements, also that these two types are not the same in all tetraploids. Although it was possible in some cases to match some individual chromosomes to two groups of the four types reported (9), studies in greater detail must be conducted before a definite conclusion can be reached as to the types of chromosome complements that have contributed. Nevertheless, the present observations permit further substantiation of the concept that all the tetraploids under study are allopolyploids. The only aneuploidy in the present study might have arisen as a result of translocation followed by elimination of a portion of chromatin material through the $B$-chromosome process. Occurrence and elimination of $B$-chromosomes has been reported in three different species of Digitaria, including pentzii (11).

On the other hand, considering the chromosome configurations in triploids which showed a high frequency of trivalents, as many as nine at diakinensis and eight at metaphase $I$, and also considering the very similar types of pachytene complements, it seems that the triploids are autotriploids-contrary to the previous concept that they are allopolyploids. These triploids may have arisen as a result of fertilization of an unreduced egg by a normal male gamete or through some other meiotic abnormalities. High pollen sterility and very poor seed setting might be due to very abnormal meiosis which results through a high frequency in formation of trivalents.

\section{SUMMARY}

Fourteen accessions of Digitaria pentzii have been studied cytologically: Ten of them are tetraploids, two are triploids, one is a diploid and one is a aneuploid. Observations made on chromosome configurations at diakinensis and metaphase 1 in polyploids, together with preliminary studies on gross morphology of pachytene chromosomes, indicate that the tetraploids are allopolyploids and the triploids are autopolyploids. Elimination of chromatin material through $B$-chromosome process following translocation is cited as one of the mechanisms for the occurrence of aneuploids.

\section{RESUMEN}

Se estudió la citología de 14 accesiones de Digitaria pentzii encontrándose que 10 de ellas son tetraploides, 2 triploides, 1 diploide y 1 aneuploide. Las observaciones hechas de las configuraciones de los cromosomas durante la diacinesis y la metafase 1 en los poliploides, junto con los estudios pre- 
liminares que se han hecho de la morfología en conjunto de los cromosomas paquiténicos, indican que los tetraploides son alopoliploides y los triploides son autopoliploides. Se cita la eliminación de la cromatina por medio del proceso de cromosomas $B$ después de la translocación, como uno de los mecanismos que explican la existencia de aneuploides.

\section{LITERATURE CITED}

1. Carnahan, H. L., and Hill, H. D., Cytology and geneties of forage grasses, Bot. Rev. 27: 1-162, 1961.

2. Degras, L. M., and Jailloux, F., Prospects for diseases and insect resistance in Digitaria, 26th Southern Pasture and Forage Crop Improvement Conference, Río Piedras, P.R., 1969.

3. Moffett, A. A., and Hurcombe, R., Chromosome numbers of South African grasses, Heredity S: 369-73, 1949.

4. Oakes, A. J., Plant exploration in South Africa, USDA publication, 1964.

5. Oakes, A. J., and Langford, W. R., Cold resistance in Digitaria, Agron. J. 69: 387-88, 1967.

6. Purcell, C. M., Embryosac development in two accessions of Giant Pangola Digitaria valida Stent, J. Agr. Univ. P.R. 49: 477-83, 1965.

7. Reeder, J. R., Notes on Mexican grasses IV. Miscellaneous chromosome numbers, Torrey Bot. Club Bull., 94, 1-17, 1967.

8. Schank, S. C., and Decker, H. F., Cytological investigations in the genus Digitaria, Soil and Crop Sci. Soc. of Fla. 27: 96-101, 1967.

9. Schambulingappa, K. G., Studies on pachytene chromosomes in the genus Digitaria, Genetica (Nether.) 88: 381-87, 1967.

10. - Cytomorphological and sterility studies in Digitaria polevansii Stent, $J$. Agr. Univ. P.R. $6 S$ (2): 106-12, 1969.

11. - Occurrence and meiotic behaviour of $B$-chromosomes in the genus Digitaria, Cytologia (in press).

12. Sheth, A. A., Yu, L., and Edwardson, J., Sterility in Pangola Grass (Digitaria decumbens Stent), Agron. J. 48: 505-07, 1956.

13. Sotomayor Ríos, A., Schertz, F., Woodbury, R., and Vélez Fortuño, J., Taxomic description and reproductive behaviour of Giant Pangola (Digitaria valida Stent.), J. Agr. Univ. P.R. 44: 53-9, 1960.

14. Swaminathan, M. S., Maggon, M. L. and Mehra, K. L., A simple propionocarmine smear method for plants with small chromosomes, Indian J. Genet. 14: 87-8, 1954.

15. Tateoka, T., Contributions to biosystematic investigations of East African grasses, Nat. Sci. Mus. Tokyo, Bull. 8, 161-73, 1965a.

16. - Chromosome numbers of some grasses from Madagascar, Bot. Mag. Tokyo 78: 306-11, $1965 \mathrm{~b}$.

17. Virkki, N., and Purcell, C. M., Observations on the behaviour, genetics and cytology of two South African Digitaria valida Stent, accessions in Puerto Rico, J. Agr. Univ. P.R. 51: 269-85, 1967.

18. Wet, J. M. J. de, Chromosome numbers and some morphological attributes of various South African grasses, Amer. J. Bot. 47: 44-9, 1960. 